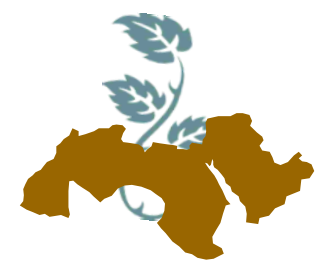

\title{
THE EFFECT OF CROSS AND RECIPROCAL CROSS ON PRODUCTIVE PERFORMANCE, FERTILITY AND HATCHABILITY FOR LOCAL CHICKEN
}

\author{
Eltohamy M.A.A., Mahrous M.Y., Lamiaa M. Radwan and Galal A. \\ Poultry Production Dept., Fac. of Agric., Ain Shams Univ., Cairo, Egypt
}

Keywords: Cross and Reciprocal cross for local breeds

\begin{abstract}
The objective of this present study is Studying the effect of crossing and reciprocal cross on productive performance, Fertility and hatchability for local chicken. The experiment was carried out in the farm of the Faculty of Agriculture - Ain Shams University. Their experimental research began when birds from two local breeds 22 week of age, where, sixty chickens (30 Fayoumi breeds, $30 \mathrm{Si}$ nai breeds).were used at 26 weeks of age semen was collected artificially from 12 cocks (6 Fayoumi , 6 Sinai).semen from each cock artificially inseminated 48 female within each breed. Were attribution taken to be a parent stock. They were housed in batteries and then they transferred into individual batteries until the end of the experiment ( 36 weeks of age). The two breeds were mated and four crosses were produced Male Fayoumi*Female Fayoumi (FF), Male Fayoumi ${ }^{\star}$ Female Sinai (FS) ,Male Sinai${ }^{\star} F e m a l e ~ S i n a i(S S)$, Male Sinai*Female Fayoumi (SF) After the second generation hatching ,the resolutely indicated that (FF) breed had the highest Fertility percent while the (SF)cross was the highest Hatchability calculated from the total eggs and also from fertile eggs . and Individual body weight (in grams) was recorded for each sex separately within each breed at $0,1,2,3,4,5$, 6, 7, 8 weeks of age. Male Sinai*Female Fayoumi (SF) was found to be the best breeds in terms of body weight and vitality and better in food conversion. The most important results observed from this study indicated that the (SF) cross had the best in fertility, the best hatchability calculated from total and fertile eggs, body weight and body weight gain.
\end{abstract}

So, it could be concluded that, cross procedure could be used in order to achieve genetic improvement from local breeds, which mean the possibility of increasing our production and hence on consumption from our local breeds and reducing on dependence from foreign breeds.

\section{INTRODUCTION}

Poultry production is one area of livestock production with significant contribution to human food production. According to CSA (2001), the chicken populations of Ethiopia in the year 2000 was estimated at about 37.8 million. Currently there are about 49.3 million chickens in the country of which 96.6\% are local chickens (CSA, 2011), indicating the significance of indigenous chickens as potential Farm Animal Genetic Resources.

Numerous scholars have evaluated the egg production potentials of crossbreds between local and exotic chicken genotypes with variable results under controlled environments (Melesse et al 2011a, b). However, limited information is available on the comparative reproductive and egg production traits of local chickens and their crosses with exotic chicken breeds under farmers' management condition. Awad and Abd El-Halim (2014) recorded that that eggs produced from the youngest flock age (40-wks-old) better $(P \leq 0.001)$ fertility and hatchability percentages of total set eggs than those from the oldest ones (60-wks-old), while embryonic mortality percent and chick weight at hatch were not significantly affected. Fertility is the major determinant of profitability in the hatchery enterprise. Peters et al, 2008. The fertility of an egg is affected by factors directly related to the laying hen such as her ability to mate successfully, store sperm, ovulate an egg cell (Brilard et al 2003) the Fayoumi and the Sinai (respectively 1331.65 and

(Received 24 December, 2017) 
1316.38g (Saadey et al 2008). The Fayoumi line, as a rural poultry group, survives normally with farmers as a scavenger chicken, but Fayoumi is a small sized hen, lays smaller eggs, has low carcass product and hence low economic return (RAJPUT et al 2005). M.A. Eltanany and S.A. Hemeda et al (2016) Sinai display higher genetic variability and singularity Compared with Fayoumi.

The objective of the present study was effected Study the effect of crossing and reciprocal cross on productive performance, Fertility and hatchability for local chicken.

\section{MATERIALS AND METHODS}

\section{Experimental design}

Their experiment began when birds from two local breeds aged 22 wks of age, sixty chickens (30 Fayoumi breed, 30 Sinai breed) were used in their study females were artificially inseminated with 12 cocks (6 Fayoumi, 6 Sinai). Each cock inseminated with 48 female within each breed. Were attribution taken to be a parent stock. They were housed in batteries and after they were transferred to individual batteries until the end of the experiment (36 weeks of age). The two breeds were mated and four cross were produced Male Fayoumi *Female Fayoumi (FF), Male Fayoumi *Female Sinai (FS), Male Sinai*Female Sinai (SS), Male Sinai *Female Fayoumi (SF) After the second generation hatching, (FF) was the highest in Fertility percent and (SF) was the highest in, Hatchability percent of total eggs and Hatchability percent of fertile eggs.

\section{Measurements and observations}

Fertility \%= (Egg fertility number / Total egg number) ${ }^{*} 100$.

Hatchability \% of total eggs $=($ Hatched egg number / Total egg number) ${ }^{*} 100$.

Hatchability \% of fertile eggs = (Hatched egg number / Egg fertility number) ${ }^{*} 100$.

\section{Productive traits}

\section{Body weight}

Individual body weight (in gram) was recorded for each sex separately within each cross at one day to eight weeks.

\section{Statistical analysis}

Data were subjected to a one-way analysis of variance with genetic group effect using the General Linear Model (GLM) procedure of (SAS User's Guide 9.0, 2002) When significant differences among means were found, means were separated using Duncan's multiple range tests (Duncan, 1955). Using the following model:

$$
Y_{i j}=\mu+B_{i}+e_{i j}
$$

Where; $Y_{i j}=$ Trait measured; $\mu=$ Overall means; $B_{i}=$ breeds effect $; e_{i j}=$ Experimental error.

\section{RESULTS AND DISCUSSION}

\section{Fertility and Hatchability percentage}

The results showed that the SS score was highest in fertility, followed SF, FS and FF, and the difference between these four crosses was insignificant, whereas in Hatchability of total eggs percent the results showed that the SF was higher, SS then FS and FF, A significant difference noticed from the SF cross in the Hatchability from fertile eggs percent followed by SS then FS and FF and the difference between these crosses was significant difference As shown in these studies, it was noticed that the SF cross had no significant difference between it and the highest SS in fertility, but the highest in the Hatchability of total eggs percent and Hatchability of fertile percent Therefore, the SF is the best cross in Fertility and hatchability percentage for off spring followed by SS then FS and FF. Shafik et al (2013) used hybridize to combine different characteristics in which the crossed breeds were valuable to improve fitness and fertility traits.

\section{Productive traits}

\section{Body weight}

The results showed that SS was the highest in weight at one day after spawning, followed by FS and then SF and FF. The difference between the four crosses was significant. After the first week, the FS cross had the highest body wt followed by SF, FF and SS. After the third week, the top SS was in weight, followed by FS and then SF and FF. The results contradicted with Shafik et al (2013) the observations of the body weights of Rhode Island Red $\times$ Fayoumi reciprocal crossbreed and 

and hatchability for local chicken

crossbreed at 23 weeks of age were 1449 and $1453 \mathrm{~g}$.

However, the difference between them was insignificant. The fourth week was higher than the SF In weight, then SS then FS and FF and the difference was significant difference, whereas the fifth week was greater than SS in weight and then SF, FF and FS were the difference between them significant difference and the sixth week SF was the highest in weight and then followed in the order FS and FF and SS and the difference between them was significant difference and after the seventh week continued SF superiority and then followed by FS and then FF and SS and the difference between these four crosses significant difference either in the eighth week was the family of SF the highest difference from the FF then the FS and SS family difference was the difference between them and hence we find that The FS were the highest first, and then the SF was significantly higher. However, from the fourth week, the SF cross started to progress from the other crosses and the superiority of the crosses continued until the eighth week. We conclude that the SF starts at lower weights in the early ages, then the weight increases and the food conversion coefficient improves. The FS family started with the highest weights in the ages First and then decreases in the increase compared with SF and it was concluded that the hybrid breeds are better than the pure breeds but prefer the SF score on FS because they are higher in the final weights.

Table 1. Fertility and hatchability percentage for off spring

\begin{tabular}{|l|c|c|c|c|c|}
\hline \multirow{2}{*}{ Traits } & \multicolumn{4}{c|}{ Crossing } & \multirow{2}{*}{ Prob. } \\
\cline { 2 - 5 } & FF & FS & SF & SS & \\
\hline Fertility \% & $94.99^{\mathrm{a}} \pm 1.67$ & $96.29^{\mathrm{a}} \pm 2.14$ & $98.33^{\mathrm{a}} \pm 1.67$ & $100^{\mathrm{a}} \pm 0$ & $\mathrm{NS}$ \\
$\begin{array}{l}\text { Hatchability \% of total } \\
\text { eggs }\end{array}$ & $80.35^{\mathrm{b}} \pm 3.42$ & $82.37^{\mathrm{b}} \pm 1.84$ & $96.66^{\mathrm{a}} \pm 1.92$ & $93.18^{\mathrm{a}} \pm 2.27$ & 0.0010 \\
$\begin{array}{l}\text { Hatchability \% of fertile } \\
\text { eggs }\end{array}$ & $76.19^{\mathrm{b}} \pm 2.33$ & $79.31^{\mathrm{b}} \pm 1.88$ & $94.99^{\mathrm{a}} \pm 1.67$ & $93.18^{\mathrm{a}} \pm 2.27$ & 0.0001 \\
\hline
\end{tabular}

Means, within the same parameter, within the row, followed by different superscripts letters differ significantly $(P$ $\leq 0.05$ ), NS, not significant.

Male FayoumiFemale Fayoumi (FF), Male Fayoumi Female Sinai (FS), Male SinaiFemale Sinai (SS), Male SinaiFemale Fayoumi (SF).

Table 2. Weekly body weight of offspring stock from one day to eight

\begin{tabular}{|c|c|c|c|c|c|}
\hline \multirow{2}{*}{ Age (wk.) } & \multicolumn{4}{|c|}{ Crossing } & \multirow{2}{*}{ Prob. } \\
\hline & FF & FS & SF & ss & \\
\hline 1day & $29.71^{b} \pm 0.53$ & $32.14^{\mathrm{a}} \pm 0.60$ & $32.05^{\mathrm{a}} \pm 0.47$ & $33.92^{a} \pm 0.73$ & 0.0006 \\
\hline 1week & $51.78^{\mathrm{b}} \pm 2.75$ & $67.14^{\mathrm{a}} \pm 2.79$ & $53.8^{\mathrm{b}} \pm 1.19$ & $49.8^{b} \pm 1.96$ & 0.0001 \\
\hline 2 week & $93.64^{b} \pm 3.18$ & $109.35^{\mathrm{a}} \pm 3.05$ & $76.03^{d} \pm 1.88$ & $84.50^{c} \pm 2.86$ & 0.0001 \\
\hline 3 week & $150^{\mathrm{a}} \pm 4.86$ & $153.93^{\mathrm{a}} \pm 6.23$ & $153.05^{\mathrm{a}} \pm 3.69$ & $158.33^{\mathrm{a}} \pm 3.75$ & NS \\
\hline 4 week & $176.07^{b} \pm 6.16$ & $176.43^{b} \pm 6.60$ & $196.80^{\mathrm{a}} \pm 5.43$ & $190^{\mathrm{ab}} \pm 5.36$ & 0.046 \\
\hline 5 week & $215^{\mathrm{b}} \pm 9.61$ & $212.14^{b} \pm 7.48$ & $244.44^{\mathrm{a}} \pm 6.42$ & $277.08^{\mathrm{ab}} \pm 7.23$ & 0.0105 \\
\hline 6 week & $288.57^{b} \pm 14.96$ & $296.43^{b} \pm 13.73$ & $338.33^{\mathrm{a}} \pm 8.22$ & $270.83^{\mathrm{b}} \pm 8.94$ & 0.0001 \\
\hline 7 week & $322.5^{\mathrm{b}} \pm 14.04$ & $331.78^{b} \pm 15.11$ & $407.08^{a} \pm 8.49$ & $304.58^{b} \pm 9.21$ & 0.0001 \\
\hline 8week & $405.71^{\mathrm{b}} \pm 17.76$ & $393.21^{b} \pm 16.87$ & $511.17^{\mathrm{a}} \pm 12.91$ & $360.37^{b} \pm 13.83$ & 0.0001 \\
\hline
\end{tabular}

Means, within the same parameter, within the row, followed by different superscripts letters differ significantly $(\mathrm{P} \leq$ 0.05), NS, not significant.

Male Fayoumi*Female Fayoumi (FF), Male Fayoumi ${ }^{\star} F e m a l e ~ S i n a i(F S)$, Male Sinai*Female Sinai (SS), Male Sinai*Female Fayoumi (SF) 


\section{REFERENCES}

Awad, A.L. and Abd El-Halim, H.A.H. 2014. some hatching traits in Sinai chicken eggs as affected by flock age, dietary ascorbic acid supplementation and egg storage period under Egyptian conditions. Egyptian Poultry Science 34, 959-978.

Brillard, J.P. 2003. Practical aspects of fertility in poultry. World Poult. Sci. J., 59, 441-446.

Duncan, D.B. 1955. Multiple range and multiple F test. Biometrics, 11, 1-42.

Eltanany, M.A. and Hemeda, S.A. 2016. Deeper insight into maternal genetic assessments and demographic history for Egyptian indigenous chicken populations using $\mathrm{m}$ t DNA analysis. J. of Advanced Research 7, 615-623.

Melesse, A. and Alewi, M. 2013. Evaluating the growth performance of local kei chickens and their f1-crosses with Rhode island red and Fayoumi breeds in watershed areas of guraghe administrative zone, southern Ethiopia. Tropical and Subtropical Agroecosystems16, 39 50.
Peters, S.O., Shoyebo, O.O., Ilori, B.M., Ozoje, M.O., Ikeobi, C.O.N. and Adebambo, O.A. 2008. Semen quality traits of seven strains of chickens raised in the humid tropics. Int. J. Poult. Sci., 7, 949-953.

Rajput, Z.I., Song-hua, H.U., Arijo, A.G., Habib M. and Khalid, M. 2005. Comparative study of Anaplasma parasites in tick carrying buffaloes and cattle. J. Zhejiang Univ. Sci. B, 6(11), 1057-1062.

Saadey, S. Mekky, A. Galal, Zaky, H.I. and A. Zein El-Dein, A. 2008. Diallel Crossing Analysis for Body Weight and Egg Production Traits of Two Native Egyptian and Two Exotic Chicken Breeds, Int. J. of Poultry Sci., 7(1), 64-71.

SAS 2002. SAS/STAT User's Guide statistics Ver. 9.0; SAS institute Inc., Cary, NC.

Shafik, Basant. M.N., El-Bayomi, Kh.M., Sosa, G.A. and Osman, A.M.R. 2013. Effect of crossing Fayoumi and Rhode island red on growth performance, egg and reproductive traits under Egyptian conditions (bvmj 24(2), 11-18 